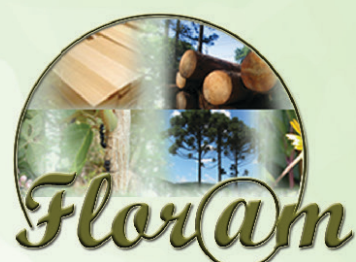

Floresta e Ambiente
Floresta e Ambiente 2018; 25(2): e038616

http://dx.doi.org/10.1590/2179-8087.038616

ISSN 2179-8087 (online)

$5+x^{2}$

Original Article

Wood Science and Technology

\title{
Use of Hevea brasiliensis Rubberwood for Glulam Beam Production
}

\author{
Luisa Julieth Parra-Serrano ${ }^{1}$, Marcia Elizabeth Marchini Piva ${ }^{2}$, \\ Aline Maria Faria Cerchiari², Israel Luiz de Lima³, José Nivaldo Garcia² \\ ${ }^{1}$ Centro de Ciências Agrárias e Ambientais, Universidade Federal do Maranhão - UFMA, Chapadinha/MA, Brasil \\ ${ }^{2}$ Departamento de Ciências Florestais, Escola Superior de Agricultura "Luiz de Queiroz" - ESALQ, \\ Universidade de São Paulo - USP, Piracicaba/SP, Brasil \\ ${ }^{3}$ Divisão de Dasonomia, Instituto Florestal de São Paulo - IF, São Paulo/SP, Brasil
}

\begin{abstract}
In Brazil, Hevea brasiliensis plantations are principally destined for latex production. In the national literature however, there are few studies on the mechanical properties of rubberwood. This study aimed to evaluate the potential of rubberwood in the manufacture of glulam beams (VLC), through the use of pieces of sawn wood of $H$. brasiliensis clone RRIM 600 glued using mono-component polyurethane adhesive. The beams were subjected to destructive bending tests according to the procedures of standard NBR 7190/97. The results were correlated with the resistance to shearing in the solid wood and the glue line. The structural performance of VLCs manufactured from rubberwood was significant when the last layer was removed from the bending calculation. This layer presented problems in the finger joint. The bending strength of VLCs is highly dependent on the tensile strength of the finger joint, which proved to be the critical point in this study.
\end{abstract}

Keywords: rubberwood, laminated wood, adhesive. 


\section{INTRODUCTION}

The rubber tree Hevea brasiliensis (Willd. ex A. Juss.) Muell. Arg, native to the Amazon region, is the most important species amongst the latex producers (Fladung \& Ewald, 2006). The greater part of global rubberwood production is concentrated in Southeast Asia, where $70 \%$ of the plantations are distributed throughout Thailand, Malaysia and Indonesia. Rubberwood, which for a long time was used solely for latex extraction, has begun to be used to manufacture panels, furniture, frames, and decorative items, and is currently a significant culture of great economic importance to the region (Lim et al., 2003; ITTO, 2009).

According to Killman \& Hong (2000), wood from this species presents favorable physical, mechanical and machinability properties, with relatively low production costs. In Malaysia, 30\% of exported wood products, and in Thailand $60 \%$, are manufactured from rubberwood (Shigematsu et al., 2011).

The principal aim of its cultivation in Brazil is natural rubber production (Gouvêa et al., 2011), however, there is no tradition of rubberwood use in Brazil (Okino et al., 2009). The planted area in 2012 was 168,848 hectares, located mainly in the states of São Paulo, Mato Grosso, Bahia, Espírito Santo, Goiás and Minas Gerais (ABRAF, 2013). In the state of São Paulo, the expansion of $H$. brasiliensis cultivation is expected to reach 250 thousand hectares by 2020 (SBS, 2008), which will generate a significant quantity of wood from this cultivar in its final rotation. According to Gonçalves (2002), the rubber trees planted in the State of São Paulo are suitable for saw milling, obtaining a production of up to $1 \mathrm{~m}^{3}$ per tree, with approximately 200 trees per hectare, allowing the extraction of 130 to 180 tons of wood per hectare, at the end of its productive cycle.

The studies from the national literature that report on the physical-mechanical performance of rubberwood from the genus Hevea, and its behavior in the manufacture of laminated products, are limited (Palma et al., 2012). Authors evaluated mechanical performance in bending of compensated $H$. brasiliensis panels. The average values of the dynamic elasticity modulus of the laminated panels varied from 4887 to $13010 \mathrm{MPa}$, with wide variation due to the radial position, while distribution in the panels directly influenced resistance to longitudinal bending.

Okino et al. (2004) characterized the use of rubberwood particles, after the latex productive cycle. They concluded that their use in the production of good quality cement-fiber boards was technically feasible, being reasonably stable in dimensional terms, independent of the clone used.

Ferreira et al. (2011) studied the average length of wood fibers of rubberwood originating from plantations in the State of São Paulo, concluding that the species presents significant differences in the average length in juvenile $(1.26 \mathrm{~mm})$ and mature $(1.51 \mathrm{~mm})$ wood fibers, a difference that influenced its machinability.

De Jesus Eufrade et al. (2015) determined that the wood from the clones RRIM600 and GT1, given its properties such as density $\left(>540 \mathrm{~kg} \cdot \mathrm{m}^{-3}\right)$, low volumetric contraction $(<10 \%)$ and high resistance in parallel compression of the fibers ( $>40 \mathrm{MPa}$ ), has applications in small and secondary structures, light construction and the furniture industry.

In civil construction, rubberwood can be considered an important material, given its functional properties and pleasing esthetic, as well as being a renewable material requiring low energy consumption. Given the scarcity of raw materials and seeking to fulfill principles of sustainability, new technologies to innovate timber use in structures are being developed. The glulam beam (VLC) technique allows for the use of small size pieces in the manufacture of structural beams. According to Pfeil \& Pfeil (2003) glulam beams generate a more homogenous material than sawed timber due to the manufacturing process, since wood knots are sectioned and distributed randomly through the manufactured piece.

The adhesive plays a fundamental role in the strength of the laminated piece, transferring tension from one laminated beam to another. The physical and chemical conditions of the surfaces during adhesion are extremely important to obtain a high performance bond (Frihart, 2010).

The objective of this study was to assess the potential of rubberwood from the species $H$. brasiliensis RRIM600 clone, in the manufacture of glued-laminated wood (GLW) based on mechanical testing of large glulam beams. 


\section{MATERIAL AND METHODS}

H. brasiliensis wood was obtained from 21-year old trees of the clone RRIM 600, originating from an experimental field cultivated in the municipality of Mococa - SP at latitude S $21^{\circ} 28^{\prime}$, longitude E $47^{\circ} 01^{\prime}$, at an altitude of $665 \mathrm{~m}$, with average annual temperature of $24.5^{\circ}$ and average annual rainfall of $155 \mathrm{~mm}$.

The trees were cut and the wood processed, being dried in a hothouse, until reaching $12 \%$ humidity. The average specific mass of the lot was $685 \mathrm{~kg} . \mathrm{m}^{-3}$. Six solid test samples of $2.5 \times 2.5 \times 41 \mathrm{~cm}$ were prepared and six VLCs with final dimensions of 5.5x $11 \times 200 \mathrm{~cm}$ were used in static bending tests. After conducting the bending test, a test sample from each one of the ends of each beam was taken, to determine resistance to shearing on the effective gluing plane of the beam. Additionally, shearing tests on solid test samples were carried out.

The wood was machined to obtain pieces with dimensions of $3 \times 7 \times 47$ and $3 \times 7 \times 70 \mathrm{~cm}$, which were visually selected. Those that contained defects, affecting their moment of inertia, were excluded.

The manufacture of the VLCs was carried out at a company specialized in the production of this engineered product. The selected pieces were profiled at the ends and joined longitudinally using finger joints. The fingers were set perpendicularly to the plane for gluing according to the typical manufacturing method used by companies in the area. The geometry and dimensions of each joint used are presented in Figure 1.

In the placement of the VLCs, the single-component polyurethane adhesive reinforced with fibers, specialized in the manufacture of engineered wood and commercially known as Jowapur 686.60 was used. Its characteristics such as containing no formaldehyde, having a neutral color and providing an elastic plane for sticking as well as being highly resistant to humidity and inclement weather are noteworthy (Jowat, 2005).

The adhesive was applied on the fingers of the pieces at a dosage of approximately $150 \mathrm{~g} . \mathrm{m}^{-2}$. The longitudinal pressure employed to join the pieces was $9 \mathrm{MPa} .200-\mathrm{cm}$ long laminated beams with randomly positioned finger joints were obtained. The laminated beams were smoothed, prior to mounting the VLCs, to obtain clean surfaces free of irregularities.

When mounting the VLCs, four laminated beams were joined together, applying the adhesive at a dosage of $250 \mathrm{~g} . \mathrm{m}^{-2}$ and spreading it evenly on the surfaces to be glued together. The laminated beams were arranged in a random manner at the height of the VLC, without applying any type of distribution according to quality. A sticking pressure of $1 \mathrm{MPa}$ was applied and maintained continuously for 1 hour and 30 minutes. After being removed from the vice, the laminated beams were smoothed and stored under controlled environmental conditions, with an average temperature of $21^{\circ} \mathrm{C}$ and relative humidity of $69 \%$ for 4 days.

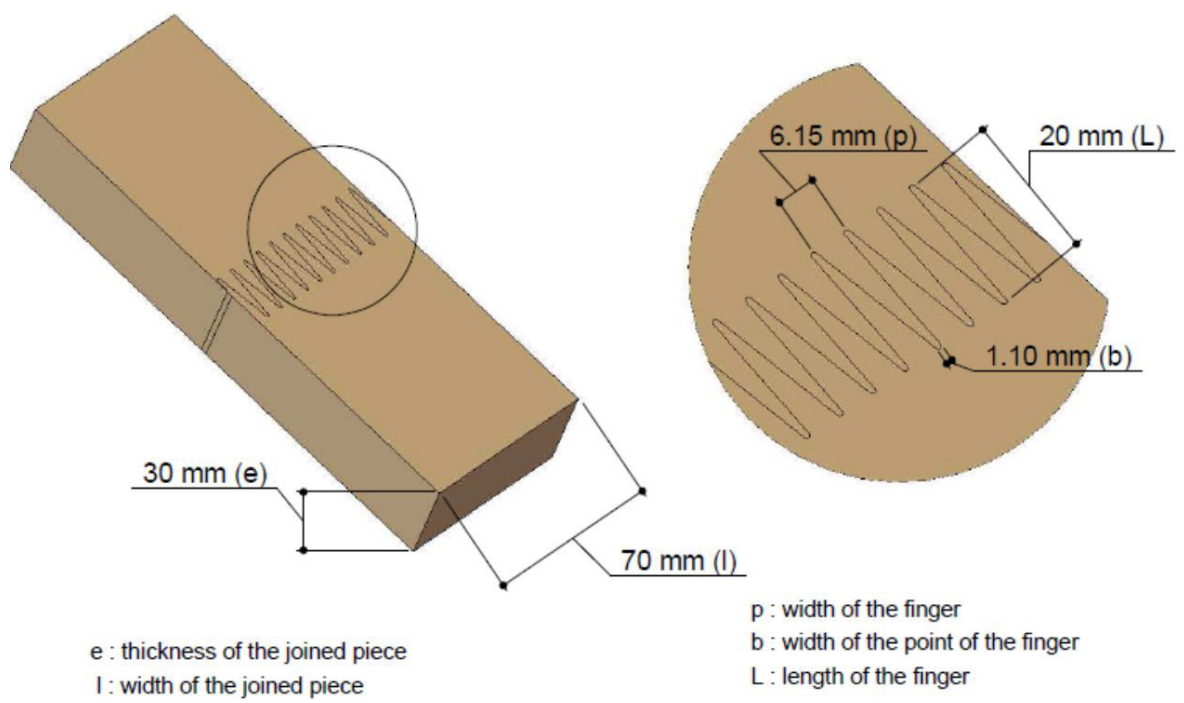

Figure 1. Geometric parameters of vertical finger joint orientation. 
The static destructive bending tests at three points (Figure 2) were carried out with certain adaptations in terms of the recommendations of Norma Brasileira NBR 7190/97 (ABNT, 1997). The gap/height ratio $(\mathrm{L} / \mathrm{h})$ was equal to 17 , and the influence of the cutting force on the arrow and consequently on the elasticity modulus can be considered negligible from a theoretical point of view (Parra-Serrano \& Garcia, 2011).

\section{Statistical analysis of the data}

The results for the evaluated mechanical properties of the solid wood and the glulam beams, were analyzed employing basic statistics (ANOVA). Average values were compared using the Tukey test at $5 \%$ probability. The tests were carried out using SAS software.

\section{RESULTS AND DISCUSSION}

The data obtained in the bending and shearing tests for the glulam beams and the solid wood are presented in Table 1 . The statistical analysis shows that there was no significant difference between the elasticity modulus in the bending $\left(\mathrm{E}_{\mathrm{M}}\right)$ of the VLCs and the solid wood. The same behavior was observed for resistance to shearing $\left(\mathrm{f}_{\mathrm{v} 0} \times \mathrm{f}_{\mathrm{gv} 0}\right)$, but there was a significant difference in the resistance to bending $\left(f_{M}\right)$.

Based on the determination of the relative efficiency of the gluing (94.13\%), which relates the results of resistance to shearing on the gluing plane of the VLCs, with the resistance to shearing of the solid wood, it can be inferred that the glue between the laminates of $H$. brasiliensis wood using the commercial single-component adhesive was satisfactory. In general, the efficiency of gluing was observed in the behavior of the laminated beams when bent, given that in the majority of the beams, rupturing did not result exclusively from the delamination of the joined pieces, but also due to shearing between the fibers of the solid pieces, which make up the laminated piece.

The breaking of the beams began at the finger joints located in the critically stretched laminated beam, from where a fissure spread in parallel to the gluing

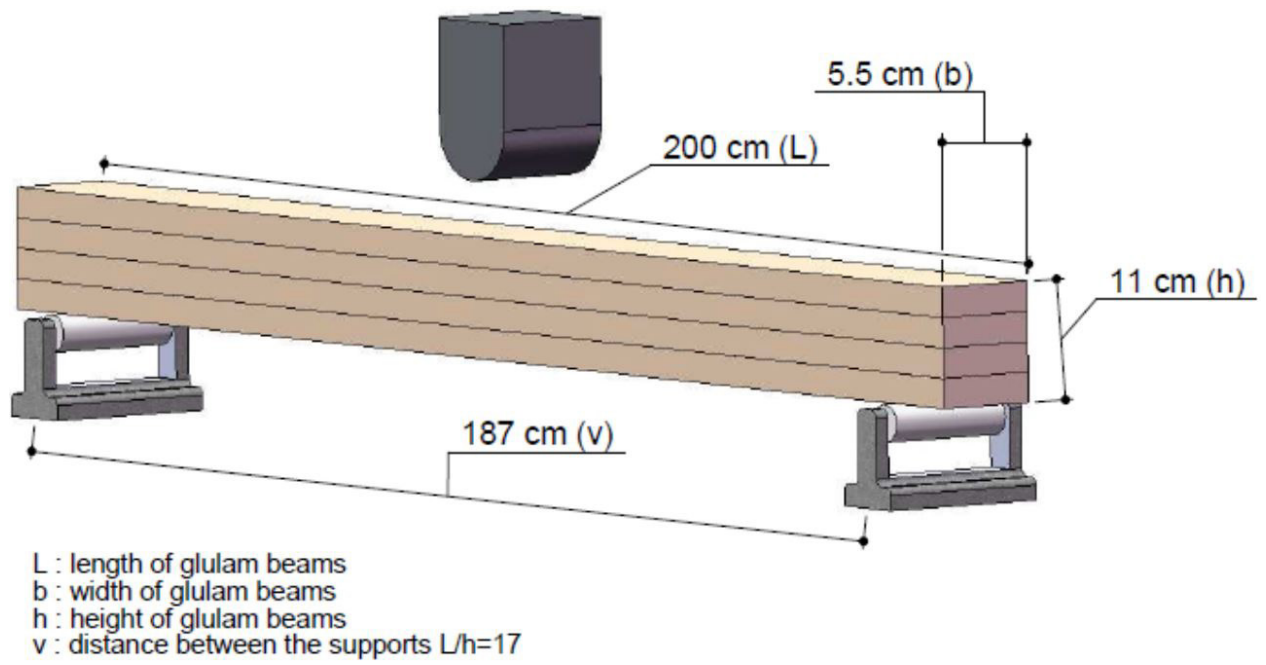

Figure 2. Schematic diagram of bending test with center-point loading to glulam beams.

Table 1. Average values for mechanical properties of glulam beams and solid wood Hevea brasiliensis clone RRIM 600.

\begin{tabular}{|c|c|c|c|c|c|c|}
\hline & \multicolumn{2}{|c|}{ Shearing } & \multicolumn{4}{|c|}{ Static bending } \\
\hline & \multicolumn{2}{|c|}{$\mathrm{f}_{\mathrm{v} 0}(\mathrm{MPa}) \mathrm{f}_{\mathrm{gv0}}(\mathrm{MPa})$} & \multicolumn{2}{|c|}{$\mathrm{f}_{\mathrm{M}}(\mathrm{MPa})$} & \multicolumn{2}{|c|}{$\mathrm{E}_{\mathrm{M}}(\mathrm{MPa})$} \\
\hline & Solid Wood & VLC & Solid Wood & VLC & Solid Wood & VLC \\
\hline Average & 10.63 & 10.00 & 83.65 (a) & 49.25(b) & 9460.49 (a) & 9776.35(a) \\
\hline Standard deviation & 0.95 & 19.22 & 16.76 & 5.74 & 3604.09 & 985.22 \\
\hline
\end{tabular}

Values followed by the same letter do not differ statistically by the Tukey test at $5 \%$ significance level. VLC = glulam beams; MPa $=$ Megapascals. 
line between the laminated beams in the direction of the section of maximum bending moment. It was observed that the form of rupture, both of the joins in the laminated beams and between the laminated beams, corresponded to mixed failures, and alternating failures on the plane of gluing with failures in the wood, indicating a strong interaction between the adhesive and the wood. In Figure 3, the details of the rupturing of each of the beams is shown, as well as the values of the elasticity modulus $\left(\mathrm{E}_{\mathrm{M}}\right)$ and of the resistance $\left(\mathrm{f}_{\mathrm{M}}\right)$ of the VLCs tested for bending.

The elasticity modulus during bending $\left(\mathrm{E}_{\mathrm{M}}\right)$ of the solid wood and the VLCs were statistically equal. The elasticity modulus was not influenced by the presence of the finger joints given that elasticity depends on the integral of the forces across the whole length of the beam, and the reduction of the moment of inertia that occurs in the effective length of the finger is negligible.

Resistance to bending (fM) of the laminated beams was critically affected by the resistance of the finger joints. Their low resistance can be attributed to a deficient connection between them, which could have been affected by the use of an insufficient quantity of adhesive, an uneven distribution on the surface of the joint and/or excessive sticking pressure.

The resistance of the VLCs corresponded to $58 \%$ of the resistance of solid wood, a fact attributed to the reduction of the moment of inertia in the joint section. The rupture of all the VLCs began in the central join of the laminated beam, which did not

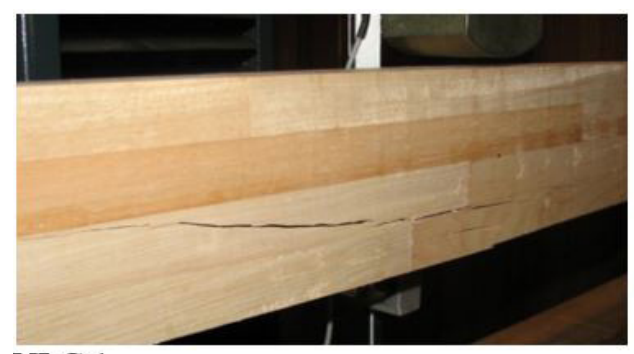

VLC 1

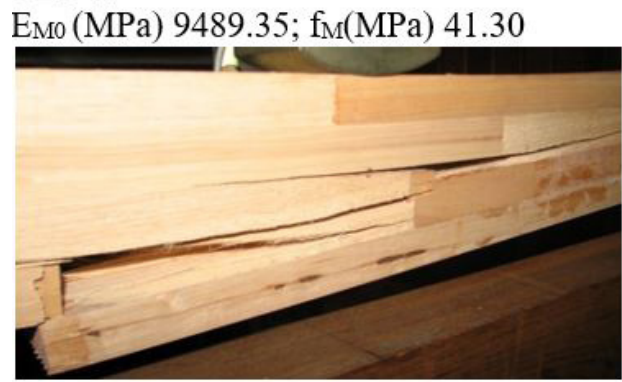

VLC 3

$\mathrm{E}_{\mathrm{M}}(\mathrm{MPa}) 8230.24 ; \mathrm{f}_{\mathrm{M}}(\mathrm{MPa}) 50.67$

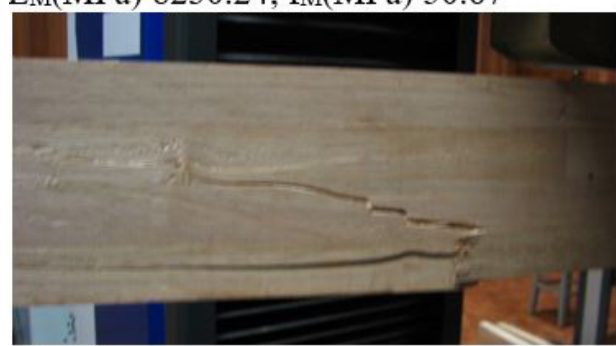

VLC 5

$\mathrm{E}_{\mathrm{M}}(\mathrm{MPa})$ 10319.66; $\mathrm{f}_{\mathrm{M}}(\mathrm{MPa}) 42.24$

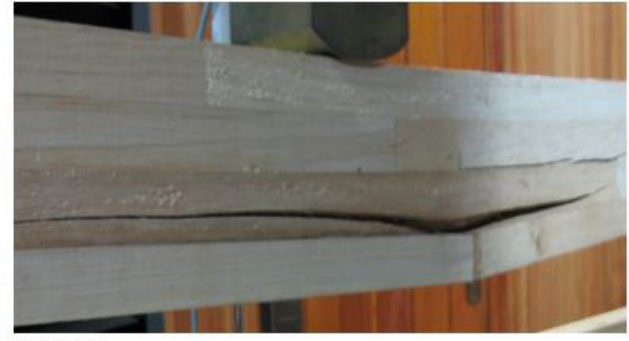

VLC 2

$\mathrm{E}_{\mathrm{M}}(\mathrm{MPa})$ 9865.57; $\mathrm{f}_{\mathrm{M}}(\mathrm{MPa}) 46.91$

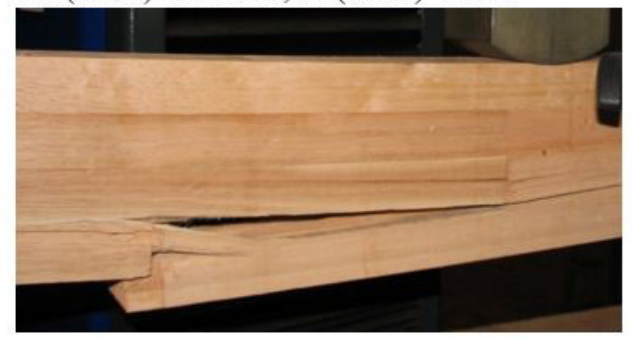

VLC 4

$\mathrm{E}_{\mathrm{M} 0}(\mathrm{MPa})$ 9553.03; f $\mathrm{M}(\mathrm{MPa}) 46.20$

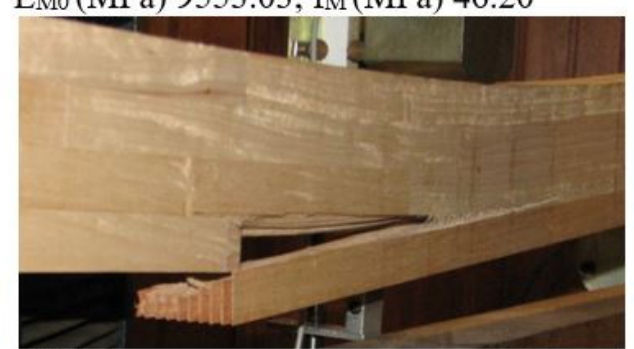

VLC 6

$\mathrm{E}_{\mathrm{M}}(\mathrm{MPa}) 11200.23 ; \mathrm{f}_{\mathrm{M}}(\mathrm{MPa}) 40.51$

Figure 3. Details of the failure mode in glulam beams, average values of modulus of elasticity $\left(\mathrm{E}_{\mathrm{M}}\right)$ and bending strength $\left(\mathrm{f}_{\mathrm{M}}\right)$ in bending test. 


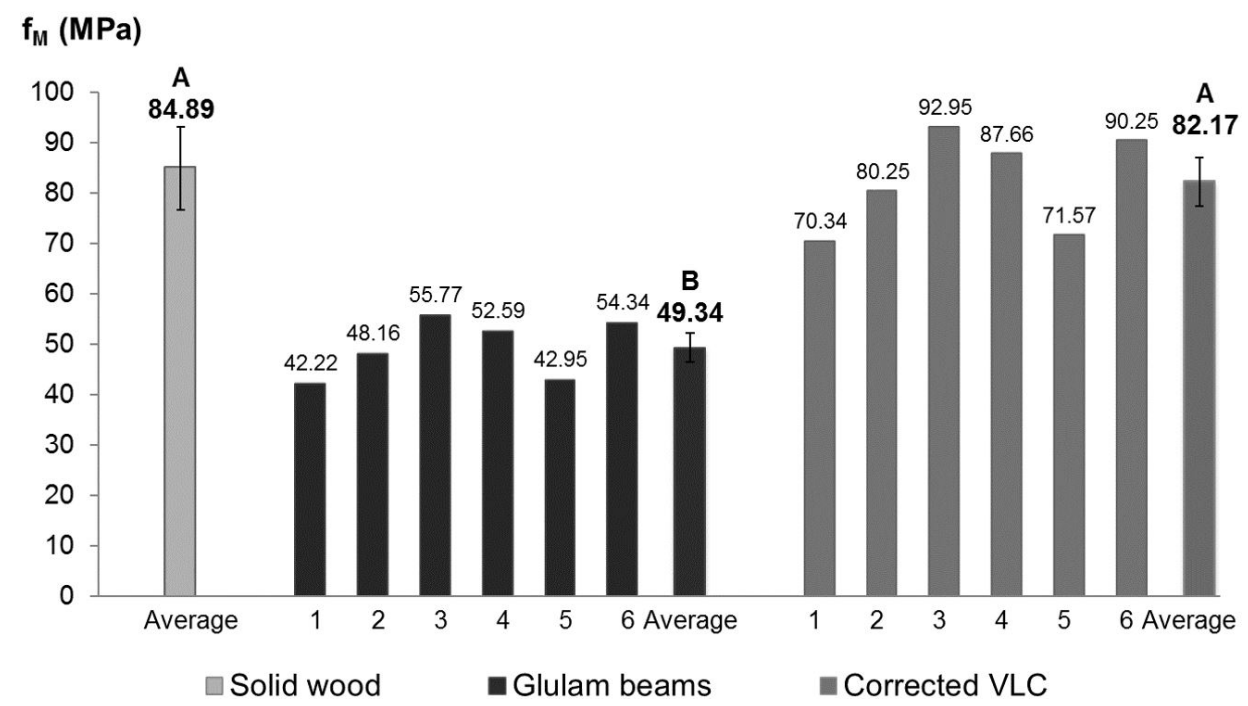

Figure 4. Bending resistance of solid wood, Glulam beams (VLC) and Glulam beams with corrected value for bending resistance (Corrected VLC). Values followed by the same letter do not differ statistically by the Tukey test at $5 \%$ significance level. VLC $=$ glulam beams; $\mathrm{MPa}=$ Megapascals.

effectively absorb the bending moment. With the fragile rupture of this glulam beam, the effective height of the beam became only three laminated beams and not the four utilized to constitute the transversal section of the VLC. The correction in the calculation of the resistance of the VLCs was made taking into account the reduced moment of inertia as presented in Figure 4. The resistance to bending of the VLCs was compared to the resistance of the solid wood.

The VLC began to present strong performance when the final laminated beam was not considered in the calculation of the moment of inertia, which generally presented a problem on the stretched edge due to the influence of the finger joints. Resistance depends on this critical section of the beam and the rupture in the last laminated beam caused by poor gluing was attributed to a lack or excess of pressure in the linear mounting of the laminated beam, an insufficient dose of adhesive or irregularities of the fingers, which affected the moment of inertia. The calculation of resistance was redone for the moment of inertia reduced by not considering the contribution of the critically stretched glulam beams.

Given all the characteristics of the wood being analyzed together with the mechanical properties of the species, it can be recommended for the manufacture of glulam beams.

\section{CONCLUSIONS}

H. brasiliensis wood of the RRIM 600 clone presents a good appearance and quality for machining, with an absence of defects such as knots and inverted grain. These characteristics together with the mechanical properties of the species made it recommendable for glulam beam manufacture.

H. brasiliensis wood presented a density of around $685 \mathrm{~kg} . \mathrm{m}^{-3}$, classified as average. This physical property aided in the obtainment of significant gluing efficiency, allowing the penetration and even distribution of the adhesive and increasing the strength of the bond. With the results obtained from the shearing resistance tests on the gluing plane, it was concluded that the single-component polyurethane adhesive is adequate and recommendable for gluing this species.

The VLCs showed good performance when the final laminated beam was removed from the calculation, which presented a problem in the finger joint. Given that resistance depends on the value of this critical section, the rupture in the last laminated beam caused by poor gluing and/or excess pressure, affected the moment of inertia, being the reason for the calculations of resistance being redone.

The resistance to bending of rubberwood VLCs is highly dependent on the resistance to the traction of the finger joints, which showed itself to be a critical point in 
the present study. The conditions of the manufacturing process should be taken into consideration in future studies to understand the correct way to increase the resistance to traction of the finger joints, which directly affects the laminated piece.

\section{ACKNOWLEDGEMENTS}

The authors are grateful for the collaboration of the Company CG SISTEMAS CONSTRUTIVOS - www. cgsistemas.ind.br - for the logistical support in the manufacture of glued laminated beams and the Jowat Klestoffe Company for the donation of the adhesive.

\section{SUBMISSION STATUS}

Received: 15 sept., 2016

Accepted: 09 june, 2017

\section{CORRESPONDENCE TO}

\section{Luisa Julieth Parra-Serrano}

Centro de Ciências Agrárias e Ambientais, Universidade Federal do Maranhão - UFMA, Br 222, Km 04, s/n, CEP 65500-000, Chapadinha, MA, Brasil

e-mail: julieth_ps@yahoo.com

\section{FINANCIAL SUPPORT}

The author Israel Luiz de Lima was supported by a National Counsel of Technological and Scientific Development (CNPq) research fellowship.

\section{REFERENCES}

Associação Brasileira de Normas Técnicas - ABNT. NBR 7190: projeto de estruturas de madeira. Rio de Janeiro: ABNT; 1997.

Associação Brasileira de Produtores de Florestas Plantadas ABRAF. Anuário estatístico da ABRAF 2013: ano base 2012. Brasília: ABRAF; 2013.

De Jesus Eufrade H Jr, Ohto JM, Silva LL, Palma LHA, Ballarin AW. Potential of rubberwood (Hevea brasiliensis) for structural use after the period of latex extraction: a case study in Brazil. Journal of Wood Science 2015; 61(4): 384-390. http://dx.doi.org/10.1007/s10086-015-1478-7.

Ferreira AL, Severo ETD, Calonego FW. Determination of fiber length and juvenile and mature wood zones from Hevea brasiliensis trees grown in Brazil. European Journal of Wood and Wood Products 2011; 69(4): 659-662. http:// dx.doi.org/10.1007/s00107-010-0510-2.

Fladung M, Ewald D. Tree transgenesis. Berlin: Springer; 2006. 360 p. https://doi.org/10.1007/3-540-32199-3.

Frihart CR. Wood adhesives, vital for producing most wood products. Forest Products Journal 2010; 61(1): 12.

Gonçalves PS. Sub-produtos complementares da renda de um seringal [online]. 2002. [cited 2014 Aug 17]. Available from: http://www.apabor.org.br/sitio/artigos/html/20020808-1.htm

Gouvêa LRL, Silva GAP, Scaloppi EJ Jr, Goncalves PS. Different methods to assess yield temporal stability in rubber. Pesquisa Agropecuária Brasileira 2011; 46(5): 491-498. http://dx.doi. org/10.1590/S0100-204X2011000500006.

International Tropical Timber Organization - ITTO. Encouraging industrial forest plantations in the tropics. Yokohama: ITTO; 2009. (Technical Series; no. 33).

Jowat A. Jowat news polyurethane adhesives with certificates [online]. Stoke on Trent: Powerbond; 2005. [cited 2015 Aug 28]. Available from: http://www.powerbond.co.uk/_images/_ attachments/second/252_2.pdf

Killman W, Hong LT. Rubberwood - the success of an agricultural by-product. Unasylva, 2000; 51(201): 66-72.

Lim SC, Gan KS, Choo KT. The characteristics, properties and uses of plantation timbers - rubberwood and Acacia mangium. Kuala Lumpur: TTO; 2003. (Timber Technology Centre, no. 26).

Okino EYA, Souza MR, Santana MAE, Sousa ME, Teixeira DE. Chapa aglomerada de cimento-madeira de Hevea brasiliensis Müll. Arg. Revista Árvore 2004; 28(3): 451-457. http://dx.doi.org/10.1590/S0100-67622004000300016.

Okino EYA, Teixeira DE, Souza MR, Santana MAE, Silva CBG, Tomaz RB et al. Uso das madeiras de seringueira, pinus e cipreste na fabricação de chapas OSB. Floresta 2009; 39(2): 457-468. http://dx.doi.org/10.5380/rf.v39i2.14573.

Palma LHA, Escobar JF, Ballarin AW, Leonello EC. Influência da qualidade das lâminas no desempenho mecânico à flexão de painéis compensados de Hevea brasiliens. Floresta e Ambiente 2012; 19(2): 133-140. http://dx.doi.org/10.4322/ floram.2012.015.

Parra-Serrano LJ, Garcia JN. Índice de influência do esforço cortante na deformação de peças de madeira por flexão. In: Anais do I Congresso Ibero-Latino Americano da Madeira na Construção - CIMAD 11;2011; Coimbra, Portugal. Coimbra: Departamento da Engenharia Civil da FCTUC; 2011.

Pfeil WE, Pfeil M. Estruturas de madeira. 6. ed. Rio de Janeiro: LTC; 2003. 224 p.

Shigematsu A, Mizoue N, Kajisa T, Yoshida S. Importance of rubberwood in wood export of Malaysia and Thailand. New Forests 2011; 41(2): 179-189. http://dx.doi.org/10.1007/ s11056-010-9219-7.

Sociedade Brasileira de Silvicultura - SBS. Fatos e números do Brasilflorestal [online]. 2008.93 p. [cited 2015 mar. 1]. Available from: http://www.sbs.org.br/FatoseNumerosdoBrasilFlores tal.pdf. 